\title{
Analisis Policy Acceptability Peraturan Daerah Kota Surabaya Nomor 2 Tahun 2019
}

\section{Policy Acceptability Analysis of Regional Regulations in Surabaya City Number 2 of 2019}

\author{
Ragilia indah lutfiana ${ }^{1 *}$, Ernawaty ${ }^{2}$ \\ ${ }^{1,2}$ Departemen Administrasi dan Kebijakan Kesehatan, Fakultas Kesehatan Masyarakat, Universitas Airlangga
}

\begin{abstract}
ABSTRAK
Latar Belakang: Merokok adalah perilaku yang memiliki dampak negatif yang membahayakan kesehatan bagi perokok aktif maupun perokok pasif. Maka dari itu, perlu adanya penerapan peraturan dan perundangan KTR untuk dapat menurunkan proporsi perokok setiap hari.

Tujuan: Tujuan dari penelitian ini yaitu menganalisis acceptability Peraturan Daerah Kota Surabaya Nomor 2 Tahun 2019 Tentang Kawasan Tanpa Rokok di Kota Surabaya.

Metode: Desain penelitian yang digunakan adalah observasional dengan pendekatan yang bersifat kuantitatif dengan rancangan studi cross sectional. Variabel terikat dari penelitian ini adalah policy acceptability. Uji statistik yang dilakukan adalah analisis korelasi linier pearson untuk mengetahui hubungan atau korelasi antara variabel dependen dan independen. Responden pada penelitian ini merupakan seluruh masyarakat yang tinggal di Kota Surabaya dengan umur 12 tahun atau lebih.

Hasil: Berdasarkan hasil penelitian dan analisis didapatkan hasil uji statistik korelasi linier pearson yang signifikan pada variabel background or individual factor adalah jenis kelamin dan pada variabel behavior adalah intention, personal autonomy, jumlah konsumsi, pengeluaran untuk merokok, usia berhenti merokok dan intention berhenti merokok.

Kesimpulan: Pemda Kota Surabaya tetap menerapkan Perda KTR, dan masyarakat senantiasa ikut berpartisipasi dalam mentaati Peraturan dengan berperilaku baik untuk menjaga kesehatan bersama.

Kata kunci: peraturan daerah, kawasan tanpa rokok, individual factor, behavior.
\end{abstract}

\begin{abstract}
Background: Smoking is a behavior that has a negative impact that is harmful to health for active smokers and passive smokers. Therefore, it is necessary to apply KTR rules and regulations to be able to reduce the proportion of smokers every day.

Objectives: The purpose of this research is to analyze acceptability of Surabaya, No. 2 of 2019 concerning NoSmoking Area in Surabaya City.

Methods: The research design used was observational with a quantitative approach to the cross-sectional study design. The dependent variable of this study is policy acceptability. The statistical test conducted was the Pearson linear correlation analysis to determine the relationship or correlation between the dependent and independent variables. Respondents in this study were all people who lived in the city of Surabaya with the age of 12 years or more.

Results: Based on the results of research and analysis obtained Pearson linear correlation statistical test results that are significant in the background variable or individual factor is gender and the behavioral variables are intention, personal autonomy, amount of consumption, expenditure for smoking, the age to stop smoking and intention to quit smoking.

Conclusion: The City Government of Surabaya continues to apply the KTR Regulation, and the community always participates in obeying the Regulations by behaving well to maintain joint health.

Keywords: local regulations, non-smoking areas, individual factors, behavior
\end{abstract}


Korespondensi:

Ragilia Indah Lutfiana

ragilia.indah.lutfiana-2017@fkm.unair.ac.id

Departemen Administrasi dan Kebijakan Kesehatan, Fakultas Kesehatan Masyarakat, Universitas Airlangga

\section{PENDAHULUAN}

Organisasi Kesehatan Dunia (WHO) menjelaskan bahwa merokok adalah penyebab global yang utama dari kematian yang dapat dicegah. Lebih dari 7 juta kematian per tahun disebabkan oleh tembakau dan kerugian ekonomi sebesar USD 1,4 trilyun. Angka ini diperkirakan akan meningkat menjadi lebih dari 8 juta kematian di tahun 2030. Indonesia adalah negara dengan konsumsi rokok terbesar di dunia, yaitu pada urutan ketiga setelah China dan India. Di tingkat Asean, Indonesia menduduki peringkat pertama dengan jumlah perokok 50,68\% dari total perokok di Asean (Departemen Kesehatan, 2018). Hal ini diperkuat oleh hasil Susenas Tahun 2016 dimana hasilnya baik di perkotaan maupun di perdesaan, persentase pengeluaran penduduk untuk kelompok rokok dan tembakau lebih tinggi $0,41 \%$ dibandingkan pengeluaran untuk kelompok bahan makanan. Meskipun bahaya rokok sudah banyak diinformasikan namun jumlah perokok di Indonesia tidak menurun, bahkan ada kecenderungan meningkat setiap tahun. Berdasarkan data Riskesdas Tahun 2018 prevalensi perokok pemula usia 10-18 tahun di Indonesia cenderung mengalami peningkatan menjadi 9,1\%, dari sebesar 7,2\% di tahun 2013, dan 8,8\% di tahun 2016. Di Provinsi Jawa Timur prevalensi merokok dari sebesar 28,9 pada tahun 2013 menjadi 28,11 di tahun 2018.

Prevalensi perokok Kota Surabaya dari tahun 2013 ke tahun 2018 mengalami penurunan, namun masih diatas 20\%. Menurut Riset Kesehatan Dasar tahun 2018, target RPJMN prevalensi perokok adalah sebesar 5,4\%. Dapat disimpulkan bahwa prevalensi perokok Kota Surabaya belum memenuhi target. Selain itu masih banyaknya perilaku merokok di Kota Surabaya juga diikuti dengan peningkatan penyakit tidak menular seperti penyakit hipertensi. Surabaya merupakan salah satu Kota dengan kasus hipertensi tertinggi di Jawa Timur pada tahun 2017 yaitu sebanyak 45.014 orang atau sebesar 10,43\% (Arum, 2019). Penyakit hipertensi ini merupakan silent killer dan dapat menimbulkan kerusakan pada ginjal, penyakit jantung koroner (PJK), dan otak yang menyebabkan stroke (Departemen Kesehatan, 2014). Demikian halnya pada penelitian (Anggraini, D.D.,and Hidajah, A.C., 2018) dikatakan bahwa, Surabaya juga merupakan salah satu kota dengan kasus PJK tertinggi. Selama tiga tahun (2014-2016) jumlah kasus mengalami peningkatan yaitu 1870 kasus pada tahun 2014, 11644 kasus pada tahun 2015, dan menjadi 12412 kasus pada tahun 2016. Hal tersebut juga sejalan dengan penelitian Diastutik (2017) yang mengatakan bahwa sebagian besar penderita penyakit jantung koroner maupun non penyakit jantung koroner memiliki riwayat merokok.

Maka dari itu, perlu adanya penerapan peraturan dan perundangan KTR untuk dapat menurunkan proporsi perokok setiap hari. Selain itu, adapun faktor lain seperti komitmen Pemerintah Daerah terhadap masalah rokok yang secara konsisten dan kongkrit diwujudkan dengan tindakan sehari-hari dalam kepemimpinannya, penegakan hukum yang konsisten dan pengawasan yang dilakukan secara rutin, kepatuhan stakeholder yang terlibat dalam penerapan kebijakan KTR yang ada, dukungan sektor pendidikan dan pariwisata terhadap penerapan KTR, dan peran aktif organisasi masyarakat, khususnya kelompok mahasiswa dan pelajar dalam melakukan kampanye anti rokok dan upaya berhenti merokok. Faktor-faktor tersebut juga berpengaruh terhadap penurunan proporsi perokok (Rahajeng, 2015).

Adapun menurut penelitian (Artanti, Lestari and Martini, 2014). yang mengatakan bahwa implementasi perda Kota Surabaya No.5 Tahun 2008 masih lemah dan masih dibutuhkannya komitmen yang kuat untuk mewujudkan Kawasan Tanpa Rokok di Surabaya. Menurut (Sekhon, Cartwright and and Francis, 2017) mengatakan bahwa suatu penerimaan akan lebih kuat jika dilakukan suatu penelitian penerimaan meskipun suatu intervensi (kebijakan) telah diterapkan. Sejalan dengan penelitian (Degeling et al., 2018), mengatakan bahwa penerimaan masyarakat meningkatkan kesadaran dan pemahaman intervensi kebijakan serta pelaksanaan pengelolaan program yang efektif. Sedangkan penerimaan/acceptability didefinisikan sebagai persepsi di antara pemangku kepentingan implementasi yang memberikan pelayanan, praktik atau inovasi berupa persetujuan, kecocokan, atau kepuasan (Proctor et al., 2011).

\section{METODE}

\section{Jenis dan Rancang Bangun Penelitian}

Desain penelitian yang digunakan adalah observasional dengan pendekatan yang bersifat kuantitatif dengan rancangan studi cross sectional. Judul penelitian ini adalah Policy acceptability Peraturan Daerah Kota Surabaya Nomor 2 Tahun 2019 Tentang Kawasan Tanpa Rokok. Variabel bebas terdiri dari behavior, information and knowledge, General belief (personal and social aims, responsibility awareness, problem perception, social norms), serta policy specific beliefs (perceived efficiency, perceived effectiveness, usability, esefulness, satisfaction, equity, affordability). Variabel terikat dari penelitian ini adalah acceptance / acceptability of policy. 


\section{Populasi Penelitian}

Populasi merupakan keseluruhan obyek yang diteliti yang terdiri dari sejumlah individu, baik terbatas (finite) maupun tidak terbatas (infinite). Populasi pada penelitian ini menggunakan populasi infinite, dikarenakan dalam hal ini seluruh masyarakat Kota Surabaya merupakan populasi yang sangat besar dan tidak terbatas.

\section{Sampel Penelitian}

Sampel pada penelitian ini sebanyak 96,04. Dari jumlah sampel tersebut maka dilakukan pembulatan untuk mempermudah perhitungan sehingga sampel yang diambil adalah sebanyak 100 responden. Dalam penelitian ini teknik pengambilan sampel yang digunakan adalah non probability sampling yaitu penarikan sampel secara tidak acak, atau semua unsur yang ada di populasi tidak mempunyai kesempatan yang sama untuk terpilih menjadi sampel. Pada pertimbangan waktu yang relatif cepat dan biaya yang relatif murah maka metode pengambilan sampel penelitian ini menggunakan accidental sampling, dengan melakukan penyebaran kuesioner google form melalui whatsapp atau yang dipandang cocok sebagai sumber data dengan kriteria sebagai berikut: Bertempat tinggal di Kota Surabaya, Berusia $\geq 12$ tahun, Bersedia menjadi responden penelitian (dengan mengisi kuesioner penelitian).

\section{Teknik dan Instrumen Pengumpulan Data}

\section{Teknik Pengumpulan Data}

Data primer diperoleh melalui wawancara terstruktur yang dilakukan pada masyarakat Kota Surabaya dengan menggunakan instrumen berupa kuesioner. Data sekunder merupakan data yang bersumber dari penelitian lain yang sudah dilakukan untuk mendukung data primer

\section{Instrumen Pengumpulan Data}

Instrumen pengumpulan data pada penelitian ini berupa pedoman kuesioner. Pedoman ini berisikan tentang latar belakang responden atau factor individual (jenis kelamin, usia, tingkat pendidikan dan pekerjaan), perilaku responden, informasi dan pengetahuan responden, general beliefs (personal and social aims, responsibility awareness, problem perception, dan social norm), serta policy specific beliefs (perceivedefficiency, perceived effectiveness, usability, usefulness, satisfaction, equity, dan affordability).

\section{Teknik Analisis Data}

Pada penelitian kuantitatif, dengan analisis deskriptif untuk menggambarkan serta menyajikan data tentang acceptancelacceptability responden terhadap kebijakan dengan faktor penentunya. Analisis menggunakan analisis analitik dibantu dengan perangkat lunak komputer, dengan tahapan analisis data sebagai berikut: Editing, Coding, Tabulasi Data.

\section{HASIL DAN PEMBAHASAN}

\section{Behavior Responden}

Dari hasil pengumpulan data menggunakan kuesioner, diperoleh 110 responden dengan distribusi frekuensi behavior atau perilaku masyarakat. Dari total responden yang pernah merokok sebanyak 16 responden, didapatkan data sebagai berikut.

Tabel 1. Distribusi Frekuensi smoking behavior berdasarkan pernah merokok pada Bulan Januari 2020

\begin{tabular}{cccc}
\hline & Berhenti merokok & Frekuensi & Persentase \\
\hline Usia berhenti & Lama (>9th) & 4 & 25 \\
merokok & Sedang (1-9th) & 12 & 75 \\
& Baru (<1th) & 0 & 0 \\
& Total & 16 & 100 \\
\hline Alasan & Kesehatan & 11 & 68,8 \\
& Ekonomi & 5 & 31,2 \\
& Total & 16 & 100 \\
\hline
\end{tabular}

Berdasarkan tabel 1 didapatkan dari total 16 responden pernah merokok, sebagian besar sudah berhenti rokok selama 1-9 tahun yaitu sebanyak 12 responden atau sebessar $75 \%$ responden. Adapun alasan responden memilih untuk berhenti merokok, sebagian besar dikarenakan alasan kesehatan yaitu sebanyak 11 responden atau sebesar $68,8 \%$ responden.

\section{Information and Knowledge Responden}

Berdasarkan hasil penelitian didapatkan frekuensi information and knoledge masyarakat Kota Surabaya sebagai berikut. 
Tabel 2. Distribusi Frekuensi Information and knowledge pada Bulan Januari 2020

\begin{tabular}{ccc}
\hline Information and knowledge & Frekuensi & Persentase \\
\hline Cukup & 41 & 37,3 \\
Rendah & 69 & 62,7 \\
Total & 110 & 100 \\
\hline
\end{tabular}

Pada tabel 2 diatas didapatkan bahwa tingkat pengetahuan responden sebagian besar masih rendah yaitu sebanyak 69 responden atau sebesar $62,7 \%$. Sedangkan sebanyak 41 responden atau sebesar 37,3\% responden mempunyai tingkat pengetahuan yang cukup. Tingkat pengetahuan responden ini diketahui dari banyaknya jawaban responden yang memilih tidak tahu dan tidak pernah membaca Perda Kota Surabaya Nomor 2 Tahun 2019 tentang Kawasan Tanpa Rokok.

General Beliefs Responden

Dari total responden sebanyak 110 responden, pada penelitian ini didapatkan hasil frekuensi general beliefs responden sebagai berikut:

Tabel 3. Distribusi Frekuensi General Beliefs Masyarakat Kota Surabaya pada Bulan Januari 2020

\begin{tabular}{cccc}
\hline \multicolumn{2}{c}{ General Beliefs } & Frekuensi & Persentase \\
\hline Personal aim & Cukup & 45 & 37,3 \\
& Rendah & 65 & 62,7 \\
& Total & 110 & 100 \\
\hline Social aim & Cukup & 83 & 75,5 \\
& Rendah & 27 & 24,5 \\
& Total & 110 & 100 \\
\hline Responsibility & Cukup & 106 & 96,4 \\
awareness & Rendah & 4 & 3,6 \\
& Total & 110 & 100 \\
\hline Problem perception & Cukup & 102 & 92,7 \\
& Rendah & 8 & 7,3 \\
& Total & 110 & 100 \\
\hline Social norms & Cukup & 62 & 56,4 \\
& Rendah & 48 & 43,6 \\
& Total & 110 & 100 \\
\hline
\end{tabular}

Berdasarkan data yang telah diperoleh pada tabel 3 didapatkan hasil personal aim responden adalah rendah yaitu sebanyak 65 responden atau sebesar $62,7 \%$ responden. Dapat diartikan bahwa sebagian besar responden tidak mementingkan tujuan individu. Pada social aim didapatkan hasil cukup yaitu sebanyak 83 reponden atau sebesar 75,5\%. Dapat diartikan bahwa sebagian besar responden lebih mementingkan kepeentingan sosial. Pada responsibility awareness didapatkan hasil cukup yaitu sebanyak 106 responden atau sebesar 96,4\% responden mempunyai responsibility awarenaess yang cukup. Sebagian besar problem perception responden juga pada kategori cukup yaitu sebanyak 102 responden atau sebesar 92,7\% responden. Begitu juga pada social norms responden berada pada kategori cukup yaitu sebanyak 62 responden atau sebesar 56,4\% responden. Sehingga dapat disimpulkan bahwa general beliefs responden pada penelitian ini sudah cukup baik. Responden yang lebih mementingkan tujuan sosial dari pada tujuan pribadi dapat menumbuhkan kesadaran dan tanggung jawab mereka untuk mengatasi masalah perilaku merokok.

\section{Policy Specific Beliefs Responden}

Pada penelitian ini, dari total responden sebanyak 110 responden didapatkan hasil frekuensi policy specific beliefs responden sebagai berikut.

Berdasarkan data yang telah diperoleh pada tabel 4 didapatkan hasil perceived efficiency responden adalah cukup yaitu sebesar 50,9\% responden. Dapat diartikan bahwa sebagian besar responden mempunyai harapan bahwa perda KTR dapat menyelesaikan masalah merokok. Pada perceived effectiveness didapatkan hasil cukup yaitu sebanyak 53,6\%. Dapat diartikan bahwa sebagian besar responden merasa ada kemudahan yang didapatkan dengan adanya perda KTR. Pada usability didapatkan hasil rendah yaitu sebesar $70 \%$ responden yang dapat diartikan bahwa responden merasa Perda KTR belum bisa dikatakan usability atau berhasil dengan tanpa adanya kesulitan.. Pada satisfaction didapatkan hasil yang rendah yaitu sebesar 65,5\% yang dapat diartikan bahwa sebagian responden belum merasa puas dengan adanya Perda KTR.. Pada equity, didapatkan hasil yang cukup yaitu sebesar 58,2\% yang dapat diartikan bahwa responden merasa Perda KTR sudah adil Pada affordability, 
didapatkan hasil yang cukup yaitu sebesar $60 \%$ yang dapat diartikan bahwa responden merasa mampu mentaati Perda KTR.

Tabel 4. Distribusi Frekuensi Policy specific Beliefs Masyarakat Kota Surabaya pada Bulan Januari 2020.

\begin{tabular}{|c|c|c|c|}
\hline \multicolumn{2}{|c|}{ General Beliefs } & \multirow{2}{*}{$\begin{array}{c}\text { Frekuensi } \\
56\end{array}$} & \multirow{2}{*}{$\begin{array}{c}\text { Persentase } \\
50,9\end{array}$} \\
\hline Perceived efficiency & Cukup & & \\
\hline & Rendah & 54 & 49,1 \\
\hline & Total & 110 & 100 \\
\hline Perceived & Cukup & 59 & 53,6 \\
\hline \multirow[t]{2}{*}{ effectiveness } & Rendah & 51 & 46,4 \\
\hline & Total & 110 & 100 \\
\hline \multirow[t]{3}{*}{ Usability } & Cukup & 33 & 30 \\
\hline & Rendah & 77 & 70 \\
\hline & Total & 110 & 100 \\
\hline \multirow[t]{3}{*}{ Usefulness } & Cukup & 56 & 50,9 \\
\hline & Rendah & 54 & 49,1 \\
\hline & Total & 110 & 100 \\
\hline \multirow[t]{3}{*}{ Satisfaction } & Cukup & 38 & 34,5 \\
\hline & Rendah & 72 & 65,5 \\
\hline & Total & 110 & 100 \\
\hline \multirow[t]{3}{*}{ Equity } & Cukup & 64 & 58,2 \\
\hline & Rendah & 46 & 41,8 \\
\hline & Total & 110 & 100 \\
\hline \multirow[t]{3}{*}{ Affordability } & Cukup & 66 & 60 \\
\hline & Rendah & 44 & 40 \\
\hline & Total & 110 & 100 \\
\hline
\end{tabular}

\section{Policy Acceptability Perda Kota Surabaya Nomor 2 Tahun 2019 Tentang KTR}

Dari total responden sebanyak 110 responden, pada penelitian ini didapatkan hasil frekuensi policy acceptability Perda Kota Surabaya Nomor 2 tahun 2019 oleh adalah responden sebagai berikut:

Tabel 5. Distribusi Frekuensi policy acceptability

\begin{tabular}{ccc}
\hline Policy Acceptability & Frekuensi & Persentase \\
\hline Cukup & 95 & 86,4 \\
Rendah & 15 & 13,6 \\
Total & 110 & 100 \\
\hline
\end{tabular}

Berdasarkan data yang telah diperoleh pada tabel 5 didapatkan hasil policy acceptability Peraturan Daerah Kota Surabaya Nomor 2 Tahun 2019 adalah cukup yaitu sebanyak 95 responden atau sebesar 74,5\% responden. Dapat diartikan bahwa sebagian besar responden menerima adanya Perda dan ingin Perda KTR tetap diterapkan di Kota Surabaya.

Dari penelitian yang telah dilakukan, didapatkan hasil analisis sebagai berikut: Dari hasil uji statistic variabel yang tidak terdapat hubungan dengan policy acceptability antara lain: jenis kelamin, usia, pendidikan, pekerjaan, social support, action situation, riwayat penyakit, personal autonomy, information and knowledge, personal aim, social aim, responsibility awareness, problem perception, social norms, perceived efficiency, perceived effectiveness, usability, usefulness, satisfaction, equity, affordability. Sedangkan variable yang memiliki hubungan dengan policy acceptability antara lain: intention, usia pertama kali merokok, antara jenis rokok, jumlah konsumsi rokok, jumlah pengeluaran untuk rokok, usia berhenti merokok, intention berhenti merokok.

\section{PEMBAHASAN}

\section{Background Responden}

Responden penelitian ini seluruhnya adalah masyarakat Kota Surabaya. Masyarakat Kota Surabaya yang dimaksud disini adalah yang berusia 12 tahun atau lebih. Berdasarkan hasil penelitian didapatkan responden dengan jenis kelamin laki-laki dan perempuan. Usia responden sebagian besar adalah usia remaja sebesar 50\%, dewasa $40 \%$, dan lansia $10 \%$. Tingkat pendidikan responden sebagian besar adalah tamat pendidikan tinggi dan pekerjaan responden sebagian besar adalah sebagian besar adalah pegawai / karyawan swasta sebesar 33\% dan tenaga kesehatan sebesar 22\%. Dalam hal ini sejalan dengan penelitian dengan karakteristik responden yang 
berlatar belakang pendidikan rendah dapat mempengaruhi perilaku. Hal ini sejalan dengan penelitian (Vlassenroot et al., 2008) bahwa faktor latar belakang atau faktor individu seperti jenis kelamin, usia, pendidikan, dan pekerjaan dapat mempengaruhi bagaimana orang berfikir yang kemudian dapat menentukan acceptance and acceptability

Tabel 6. Hasil Uji Correlations Policy Acceptability

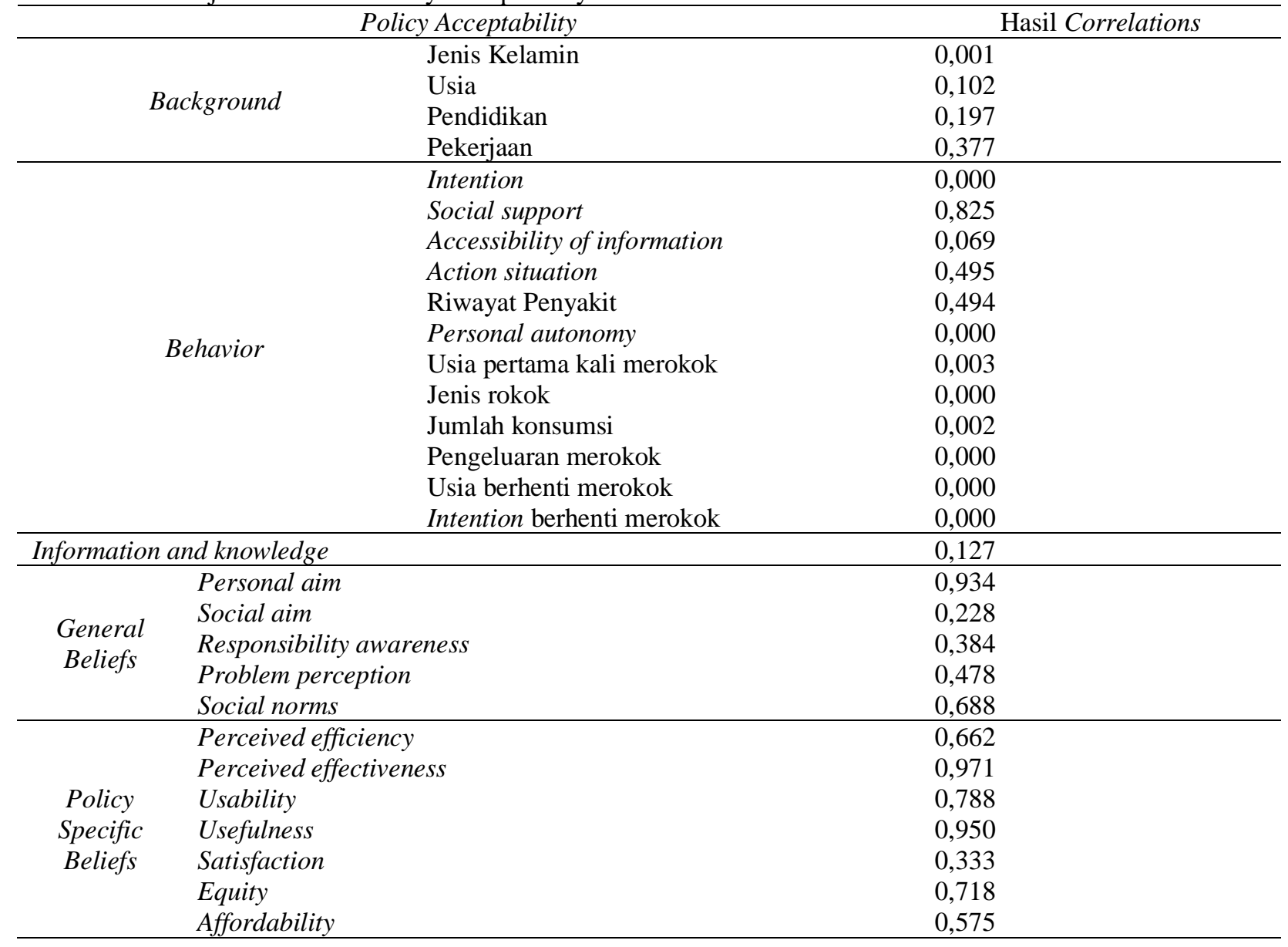

\section{Behavior Responden}

Responden pada penelitian ini, didapatkan sebagian besar tidak pernah merokok yaitu sebesar $59 \%$ dan responden pernah merokok atau responden yang telah berhenti merokok sama sekali sebesar 20\%. Dalam hal ini sejalan dengan penelitian (Vlassenroot et al., 2008) tentang perilaku perjalanan, gaya mengemudi, dan pilihan kendaraan, dapat menjadi alasan untuk menentukan acceptance and acceptability pada kebijakan sistem kecepatan mobil, yang pada penelitian ini perilaku merokok merupakan suatu masalah, yang kemudian juga dapat berpengaruh terhadap acceptance and acceptability pada Perda KTR.

\section{Information and knowledge Responden}

Tingkat pengetahuan responden pada penelitian ini didapatkan hasil yang rendah sebesar 62,7\%. Rendahnya tingkat pengetahuan ini diketahui dari banyaknya responden yang memilih jawaban tidak tahu tentang adanya perda dan tidak pernah membaca isi dari Perda. Hal ini sejalan dengan penelitian. (Schade, J., and Schlag, 2003) dan penelitian (Steg, Dreijerink and And Abrahamse, 2005) bahwa tingkat acceptance dan acceptability dapat tergantung pada seberapa tau responden tentang masalah dan tentang kebijakan baru yang diperkenalkan untuk memecahkan masalah. Pada penelitian (Vlassenroot et al., 2008) dan penelitian (Rogers, 2003) juga menjelaskan bahwa informasi yang di ketahui responden tentang masalah atau tentang Perda, akan mempengaruhi penerimaan. Selain itu pada penelitian (Regan et al., 2003) juga menjelaskan bahwa kesadaran responden yang ditentukan oleh pengalaman juga dapat menentukan acceptability.

\section{General Beliefs Responden}

Hasil personal aim responden adalah rendah yaitu sebesar $62,7 \%$ responden yang diartikan bahwa sebagian besar responden tidak mementingkan tujuan individu. Pada social aim didapatkan hasil cukup yaitu sebanyak $74,5 \%$ yang diartikan bahwa sebagian besar responden lebih mementingkan kepeentingan sosial. Dalam hal ini 
sejalan dengan penelitian (Schade, J., and Schlag, 2003) yang mengatakan bahwa kepentingan tujuan pribadi dan sosial merupakan suatu hal yang membentuk dilema individu untuk menentukan penerimaan terhadap suatu hal

Pada responsibility awareness didapatkan hasil cukup yaitu sebanyak 95,5\% responden mempunyai responsibility awarenaess yang cukup. Hasil penelitian ini sejalan dengan penelitian (Schwartz, 1977) yang mengatakan bahwa kesadaran dan tanggung jawab sangat berkaitan dengan tujuan pribadi dan sosial individu. Tingkat kepentingan mana yang individu pilih merupakan wujud dari kesadaran dan tanggung jawab individu sendiri terhadap suatu masalah. Selain itu juga sejalan dengan penelitian (Schade, J., and Schlag, 2003) dan penelitian (Steg, Dreijerink and And Abrahamse, 2005) yang menyatakan hubungan positif antara kesadaran, tanggung jawab dengan masalah penerimaaan.

Pada penelitian ini, sebagian besar problem perception responden pada kategori cukup yaitu sebesar 91,8\% responden. Dalamhal ini sejalan dengan penelitian (Schade, J., and Schlag, 2003) penelitian (Steg, Dreijerink and And Abrahamse, 2005) dan penelitian (Vlassenroot et al., 2008) menjelaskan bahwa diperlukan penyamaan persepsi sejauh mana suatu hal dianggap masalah sehingga dapat meningkatkan penerimaan solusi untuk memecahkan masalah.

Pada social norms responden dalam phasil penelitian ini didapatkan berada pada kategori cukup yaitu sebesar 56,4\% responden. Dalam hal ini sejalan dengan penelitian (Ajzen, 2002) bahwa norma sosial merupakan faktor yang mengacu pada asumsi individu tentang Apakah rekannya akan berpikir bahwa ia harus menerima kebijakan. Hal ini diasumsikan bahwa teman sebaya atau rekan kerja akan mempengaruhi sikap atau perilaku individu, sehingga dapat dikatakan bahwa banyaknya teman yang menganggap merokok adalah suatu masalah maka akan mempengaruhi pemikiran individu. Begitu juga jika banyak teman yang menerima Perda, maka hal tersebut juga akan mempengaruhi peneimaaan individu.

\section{Policy Specific beliefs Responden}

Berdasarkan hasil penelitian didapatkan hasil perceived efficiency responden adalah cukup yaitu sebesar $50,9 \%$ responden yang diartikan bahwa sebagian besar responden mempunyai harapan bahwa perda KTR dapat menyelesaikan masalah merokok. Pada perceived effectiveness didapatkan hasil cukup yaitu sebanyak 53,6\%. Dapat diartikan bahwa sebagian besar responden merasa ada kemudahan yang didapatkan dengan adanya perda KTR. Pada usability didapatkan hasil rendah yaitu sebesar $70 \%$ responden yang dapat diartikan bahwa responden merasa Perda KTR belum bisa dikatakan usability atau berhasil dengan tanpa adanya kesulitan. Pada satisfaction didapatkan hasil yang rendah yaitu sebesar $65,5 \%$ yang dapat diartikan bahwa sebagian responden belum merasa puas dengan adanya Perda KTR.. Pada equity, didapatkan hasil yang cukup yaitu sebesar 58,2\% yang dapat diartikan bahwa responden merasa Perda KTR sudah adil Pada affordability, didapatkan hasil yang cukup yaitu sebesar 60\% yang dapat diartikan bahwa responden merasa mampu mentaati Perda KTR.

Dari segi efisiensi, sejalan dengan penelitian (Vlassenroot et al., 2011) mengatakan bahwa yang dirasakan oleh individu, menunjukan kemungkinan besar manfaat sesuai dengan harapan dibandingakan dengan hal yang lain. Pada efektivitas mengacu pada fungsi sistem sesuai dengan spesifikasi desain, untuk dapat berfungsi (Young et al., 2003). Sedangkan pada penelitian ini, apakah kebijakan Perda KTR dapat berjalan sesuai fungsi dan tujuannya adatu tidak. Pada usability dan usefulness sejalan dengan penelitian (Landwehr, 2005) bahwa keramahan kebijakan dapat dikaitkan dengan kegunaan. Individu akan mengharapkan layanan yang tidak membebani mereka.

Pada usefulness merupakan faktor yang terkait dengan bagaimana sistem akan mendukung perilaku individu sehingga meningkatkan kepercayaan seseorang dimana dengan adanya sistem akan meningkatkan kinerjanya. Pada equity merupakan faktor yang mengacu ada distribusi biaya dan manfaat yang pada penelitian (Schade, J., and Schlag, 2003) menjelaskan hal tersebut merupakan hal penting berupa keadilan dalam pelaksanaan kebijakan yang akan dapat mempengaruhi penerimaan. Pada tingkat kepuasan sejalan dengan penelitian (Van der Laan, Heino and and de Waard, 1997) yang mengatakan bahwa kepuasan hanya akan digunakan untuk mengukur penerimaan. Pada faktor keterjangkauan dapat diasumsikan bahwa status sosioekonomi akan mempengaruhi acceptance dan acceptability (Rogers, 2003). keterjangkauan akan tergantung pada anggaran individual dan/atau dana publik/swasta yang merupakan merupakan suatu faktor kemampuan dari individu untuk dapat berkontribusi melaksanakan kebijakan (Vlassenroot et al., 2008).

\section{Policy acceptability Perda KotaSurabaya Nomor 2 Tahun 2019 tentang KTR}

Hasil policy acceptability Peraturan Daerah Kota Surabaya Nomor 2 Tahun 2019 adalah cukup yaitu sebesar 74,5\% responden. Dapat diartikan bahwa sebagian besar responden menerima adanya Perda dan ingin Perda KTR tetap diterapkan di Kota Surabaya. Dalam hal policy acceptability, pada penelitian (Vlassenroot et al., 2008) menjelaskan bahwa penerimaan, akseptabilitas, penerimaan sosial, dukungan publik, dukungan sosial merupakan istilah yang sering digunakan untuk menggambarkan bagaimana potensi pengguna bertindak dak bereaksi jika ukuran tertentu diimplementasikan. Berdasarkan uraian diatas dapat didefinisiakan bahwa policy acceptability merupakan suatu sikap penerimaan sebelum dan sesudah diterapkan atau dilaksanakannya suatu kebijakan. Dalam penelitian ini dapat dikatakan bahwa masyarakat Kota Surabaya merespon positif tentang 
adanya perda dan perespon positif juga untuk tetap di terapkannya Perda Kota Surabaya Nomor 2 tentang Kawasan Tanpa Rokok.

Pada penelitian (Young et al., 2003) yang mengatakan penerimaan akan bergantung pada berapa kebutuhan pengguna yang terintegrasi dalam pengembangan sistem, apakah sistem cukup baik untuk memenuhi kebutuhan. Sejalan dengan enelitian tersebut, pada penelitian penerimaan Perda ini juga dipengaruhi oleh adanya background responden yang cukup, behavior yang cukup, dan di dorong pula oleh general belief responden dan policy specific beliefs responden yang menganggap perilaku merokok merupakan suatu masalah serta adanya Perda merupakan suatu solusi, sehingga terjadi adanya penerimaan Perda Kota Surabaya Nomor 2 Tahun 2019 Tentang Kawasan tanpa Rokok.

\section{KESIMPULAN}

Behavior responden pada penelitian ini, didapatkan sebagian besar idak pernah merokok atau dapat dikatakan berperilaku baik. Tingkat pengetahuan responden pada penelitian ini didapatkan hasil yang rendah. General beliefs pada masyarakat Kota Surabaya, didapatkan sebagian besar responden tidak mementingkan tujuan individu dan sebaliknya pada social aim didapatkan hasil cukup. Pada responsibility awareness didapatkan hasil cukup. Sebagian besar problem perception responden juga pada kategori cukup. Begitu juga pada social norms responden berada pada kategori cukup.

Pada Policy specific beliefs didapatkan hasil perceived efficiency, perceived effectiveness, equity pada kategori cukup yang diartikan bahwa harapan dan kemudahan serta keadilan yang didapatkan responden dengan adanya KTR. Selain itu sebagian besar responden mampu untuk melaksanakan Perda sudah pada kategori cukup. Sehingga meskipun pada usability dan satisfaction didapatkan hasil rendah namun itu masih dapat diperbaiki dengan adanya harapan masyarakat dan kemampuan masyarakat untuk untuk melaksanakan Perda KTR.

Hasil policy acceptability Peraturan Daerah Kota Surabaya Nomor 2 Tahun 2019 adalah cukup yang dapat diartikan bahwa sebagian besar responden menerima adanya Perda dan ingin Perda KTR tetap diterapkan di Kota Surabaya. Dalam penelitian ini dapat dikatakan bahwa masyarakat Kota Surabaya merespon positif tentang adanya perda dan perespon positif juga untuk tetap di terapkannya Perda Kota Surabaya Nomor 2 tentang Kawasan Tanpa Rokok.

Berdasarkan hasil penelitian dan analisis didapatkan hasil uji statistik korelasi linier pearson yang signifikan pada variabel background or individual factor adalah jenis kelamin dan pada variabel behavior adalah intention, personal autonomy, jumlah konsumsi, pengeluaran untuk merokok, usia berhenti merokok dan intention berhenti merokok.

\section{ACKNOWLEDGEMENT}

Penulis mengucapkan terima kasih kepada seluruh staf pengajar Fakultas Kesehatan Masyarakat Universitas Airlangga atas bimbingan dan bantuan selama pelaksanaan penelitian ini dan para pasien yang telah bersedia menjadi responden.

\section{DAFTAR PUSTAKA}

Ajzen, I. (2002) 'Attitudes, personality and behaviour (2 ed)', Buckingham: Open University Press. doi: 10.4135/9781446249215.n22.

Anggraini, D.D.,and Hidajah, A.C. (2018) 'Kejadian penyakit jantung koroner pada perempuan usia produktif', Amerta Nutr Journal.Universitas Airlangga Surabaya.

Artanti, K. D., Lestari, K. S. and Martini, S. (2014) 'Evaluasi implementasi perda kota surabaya no.5 tahun 2008 tentang KTR dan KTM pada tahun 2013 di fasilitas kesehatan.', Proceeding The 1st Indonesian Conference on Tobacco or Health (ICTOH), 30(2), p. 176. doi: 10.22146/jh.v30i2.33645.

Arum, Y. T. G. (2019) 'Hipertensi pada penduduk usia produktif (15-64 tahun)', HIGEIA Journal Of Public Health Research And Development. Universitas Negeri Semarang. doi: 10.24198/jkg.v30i3.18532.

Degeling, C. et al. (2018) 'Assessing the public acceptability of purposed interventions to reduce the misuse of antibiotic in australia: a report on two cmmunity juries', Health Expect Journal. Sydney. doi: 10.1111/hex.12589.

Departemen Kesehatan (2018) 'Pusat Data dan Informasi Kementerian Kesehatan Republik Indonesia', Kementrian Kesehatan Republik Indonesia. Jakarta: Indonesia. doi: 1 Desember 2013.

Van der Laan, J. D., Heino, A. and and de Waard, D. (1997) 'A simple procedure for the assessment of acceptance of advanced transport telematics', Transportation Research Part C: Emerging Technologies. doi: $10.1526 / 003601107781170026$.

Landwehr, J. (2005) 'VOC: a bibliography of publications relating to the Dutch East India Company,1602- 
1800.', Netherlands: HES \& DE GRAAF Publisher. doi: 10.1007/s10584-006-9059-9.

Proctor, E. et al. (2011) 'Outcomes for Implementation Research: Conceptual Distinctions, Measurement Challenges, and Research Agenda', Administration and Policy in Mental Health and Mental Health Services Research. doi: 10.1177/1363459315574117.

Rahajeng, E. (2015) 'Pengaruh penerapan kawasan tanpa rokok terhadap penurunan proporsi perokok di provinsi daerah istimewa yogyakarta dan bali’, Jurnal Ekologi Kesehatan. doi: 10.26502/jfsnr.2642-1100001.

Regan, M. A. et al. (2003) 'On-Road Evaluation of intelligent Speed Adaptation, Following Distance Warning and Seatbelt Reminder System: Final Results of the TAC SafeCar Project Victoria':, Monash University Accident Research Centre. doi: 10.1922/CDH.

Rogers, E. M. (2003) 'Diffusion of Innovations', The Free Press. New-York. doi: 10.1922/CDH.

Schade, J., and Schlag, B. (2003) 'Acceptability of urban transport pricing strategies.', Transportation Research Part F: Traffic Psychology and Behaviour. BMC Public Health. doi: 10.1186/s12889-015-2415-9.

Schwartz, S. (1977) 'Normative influence on alturism', Advances in Experimental Social Psychology. doi: 10.1186/1471-2407-14-943.

Sekhon, M., Cartwright, M. and and Francis, J. J. (2017) 'Acceptability of healthcare interventions: an overview of reviews and development of a theoretical framework', BMC Health Services Research. BMC Health Services Research. doi: 10.1186/s12913-017-2031-8.

Steg, L., Dreijerink, L. and And Abrahamse, W. (2005) 'Factors influencing the acceptability of energy policies: a test of vbn theory.', Journal Of Environmental Psychology. doi: 10.1177/0013916503251466.

Vlassenroot, S. et al. (2008) 'Measuring acceptance and acceptability of its theoretical background in the development of a unified concept.', TRAIL Research School. Delft, (January).

Vlassenroot, S. et al. (2011) 'What driver the acceptability of Intelligent Speed Assistance (ISA)', European Journal of Transport and Infrastructure Research. doi: 10.1016/j.tra.2008.03.006.

Young, K. L. et al. (2003) 'Acceptability of In-vehicle Intelligent transport systems to Young Novice Drivers in New South Wales', Victoria: Monash University Accident Research Centre (Muarc). doi: 10.1016/j.enpol.2011.03.006. 